\title{
A Mycorhiza from the Lower Coal-Measures.
}

\author{
BY
}

\author{
F. E. WEISS, D.Sc., F.L.S., \\ Professor of Botany in the Victoria University of Manchester.
}

With Plates XVIII and XIX and a Figure in the Text.

$A^{L L}$ who have investigated the microscopic structure of fossil plants $\mathrm{A}$ are familiar with traces of fungal hyphae and occasional fungal sporangia in and around the plant-remains. An excellent critical account of our knowledge of such fossil Fungi will be found in Seward's 'Manual of Fossil Plants' ('98), in which he has not only recorded the Fungi described by Williamson, Renault, Conwentz, and other observers, but discusses their possible systematic position. In summing up our knowledge of this group of plants, he remarks that 'we have fairly good and conclusive evidence of the existence in Permo-Carboniferous times of Phycomycetous Fungi.'

Judging from the appearance of the tissues in which these Fungi are found, one is led to the conclusion that they were for the greater part of a saprophytic nature. This would seem more particularly so in the case of the fossil plants from the English Coal-Measures, the internal structure of which is so fully known from the remains found in the nodular concretions, the so-called 'coal-balls' of the Bullion Coal. In these coal-balls, which, according to Lomax ('02), were probably not formed in situ, the plantremains are often of a very fragmentary character, and show traces of having undergone considerable decomposition. The tissues are often penetrated by Stigmarian rootlets, and show signs of having been bored by wood-eating animals. They also show not infrequently internal mycelia, while apparent fungal sporangia are found both within the fossil plants and in the débris lying between them. Indeed, the conditions under which these nodules were formed would seem to have been most favourable for the growth of saprophytic Fungi. Some of the fossil Fungi, however, from the silicified nodules at Grand Croix which have been described by Renault ('83) and Bertrand ('85), and more recently by Oliver ('03), seem to have been of a parasitic nature and to have belonged probably to the group of Chytridiaceae. One form, indeed, which appears to have been parasitic on the 
fronds of Alethopteris aquilina, Magnus ('03) considers sufficiently like the recent form Urophlyctis to warrant its inclusion in that genus.

From the observations so far made we are able to picture to a certain extent the modes of life of the Fungi in Palaeozoic times, and we come to the conclusion that they differed very little from those of recent Fungi.

But, besides leading saprophytic or parasitic existence, Fungi are at the present day also found living together with green plants in a state of symbiosis, in which they do not destroy the tissues of the green plant, but seem rather to be of some use to it, while at the same time they derive some benefit from the green plant. Living in such mutual relations with algal cells, the Fungi form the group of organisms known as Lichens, while when they inhabit the roots or root-stocks of many higher plants they form the so-called mycorhiza, the significance of which is still under discussion. Remains of Lichens are, according to Schimper and Schenk ('90), known from the Tertiary period, some of them being preserved in Amber; but none have so far been recorded from Secondary rocks. Mycorhizae, on the other hand, have to my knowledge not been described in a fossil condition. Yet, at the present time this peculiar association of Fungi with the roots of higher plants is a fairly widespread phenomenon. This is perhaps more particularly the case in tropical forests, where, according to Janse's investigations, sixty-nine plants out of seventy-five chosen from various divisions of the vegetable kingdom had their roots inhabited by apparently symbiotic Fungi. Whatever may ultimately turn out to be the significance of these endophytic Fungi, there can be no doubt that this mutual adaptation represents a considerable specialization of the two organisms forming the Mycorhiza. The latter might, therefore, be expected to have arisen at a comparatively recent period in the evolution of plants. But apparently this form of symbiosis is of considerable antiquity, for it seems to have existed as far back as the Lower Coal-Measures. I am conscious that this announcement will very naturally meet with some scepticism; nevertheless, I venture to think that the evidence which will be brought forward in the following pages warrants the conclusion that this highly specialized mutual adaptation of Fungus and cormophyte did actually exist in the Palaeozoic age.

The root or rhizome in question I found on two slides in the Cash collection of Coal Measure plants in the Manchester Museum, Owens College (slides No. Q527 and Q 529), both from the Halifax Hard Bed, which, according to Binney ('62), must be correlated with the Bullion Mine of the Burnley district and the Gannister Mine of Dulesgate, Todmorden. These three seams of the Lower Coal-Measures are characterized by the possession of the nodular concretions (coal-balls) referred to above, and it is from one of these that the preparations were made. On communicating my view of the nature of these specimens to Dr. Scott, he very generously placed at my disposal 
a similar specimen from the collection of the late Mr. James Spencer, of Halifax, which he had purchased some years ago. It turned out to be undoubtedly of the same nature as the specimens in the Cash Collection, and is in all probability from the same locality, as most of Mr. Spencer's material came from the Halifax Hard Bed.

\section{The Host Plant.}

The only remains that we have of the host plant are a few delicate root-like organs ranging from about $\mathrm{I}$ to $2 \mathrm{~mm}$. in thickness. In all the specimens so far discovered the tissues are well preserved in comparison with the surrounding plant-remains, which have for the most part undergone considerable destructive changes. Among the débris are seen sporecases, apparently of a fungal nature, and numerous opaque, rounded masses (see P1. XVIII, Fig. I), which are generally taken to be excrements of woodboring animals. The whole has the aspect of a mass of humus in which Fungi and animal organisms were causing a gradual breaking-down of the vegetable remains. Only a few hard macrospores, some Stigmarian rootlets, and the mycorhiza in question seem unaltered $-\mathrm{a}$ fact which is suggestive of their having grown in the humus-like mass.

The internal structure of the mycorhiza at once suggests a root of the diarch type, but differs in several respects from other diarch roots found among Coal Measure plants. It should be added that these root-like remains are very constant in character, and therefore easily recognizable. As seen in Pl. XVIII, Fig. I, the root has two groups of wood distinctly separated by well-marked ground-tissue cells. These are present in all the specimens, and as the larger ones are evidently mature we may consider that the xylem-rays did not meet in the adult organ, as is generally the case in the roots of Ferns. In a smaller specimen than that in Fig. I these medullary cells are filled with curious granules (P1. XVIII, Fig. 2, and Text-fig. 42), the nature of which is uncertain. At first sight they closely resemble a number of starch-grains, but it is somewhat doubtful whether starch would be preserved with quite so definite an outer boundary. On the other hand, they do not seem in any way connected with the Fungus, which does not as a rule penetrate to such depths; nor does the Fungus in other parts of the plant, where it occurs, produce granules quite of this kind. It would, therefore, seem more probable that the granules are the normal cell-contents at a certain stage in the development of the organ or under certain conditions of nutrition.

With regard to the xylem-groups, it is not always easy, or indeed possible, to distinguish the protoxylem-elements. In Fig. 2 the smaller elements seem to be on the outside of the wood; but, as will be seen from Fig. I, this is not always the case. In one group, indeed, the smaller elements appear to be on the inside. Their position is in fact irregular, and 
in that respect, as well as in others to which reference will be made later on, the stele resembles somewhat that of the rhizome of Psilotum. It is true that in this latter plant the xylem-rays, whether two or more, are generally connected in the centre ; but in certain parts of the plant, according to Bertrand's ('82) figures and description, the xylem-groups may remain separate. Owing to the uncertainty as to the position of the protoxylem, I prefer, therefore, to leave it an open question whether the organ under consideration was a root or a rhizome. If the latter, then it must have

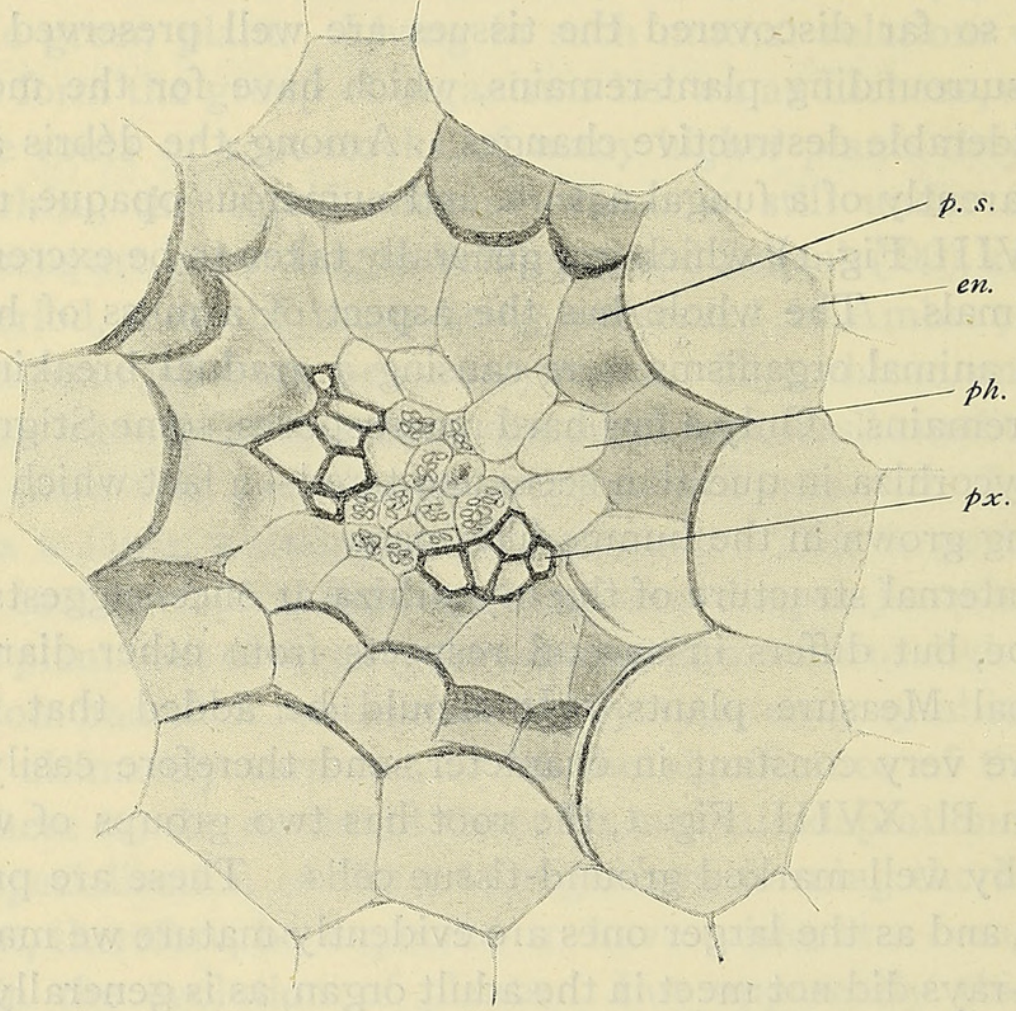

FIG. 42. Enlarged drawing of stele from specimen represented in Fig. 2, P1. XVIII. The protoxylem elements $(p x)$ are on the outside of the groups of wood. The ground tissue is filled with granules (starch?). The stele is surrounded by a distinct endo-cortex (en) within which is a phloem-sheath (p.s.).

been a leafless rhizome of the type found in the Psilotaceae or in Corysanthes, Corallorhiza, and some other Saprophytes.

In longitudinal section, as seen in Plate XVIII, Fig. 3, which is taken from Dr. Scott's specimen, it will be seen that the xylem consists mainly of scalariform tracheids. I have in fact not been able to discover any other elements in the longitudinal section; but it is of course possible that the latter did not pass through the spiral elements if such were present in the plant. There are no very clearly-marked phloem elements, though certain cells on either side of the xylem-groups might be considered as bast cells $(p h)$. In this respect we have another agreement with Psilotum and also with other Lycopodiaceous plants in which the phloem is not made up of well-defined sieve-tubes. Similarly in some cases, as in Plate XVIII, Fig. 2, 
there is an indication of a phloem-sheath (p.s.) or pericycle. The characteristics of these tissues are not well pronounced, and except for the xylem-groups the structure of the stele is somewhat unsatisfactory.

The cortical tissues are well developed and consist of thin-walled cells. There is no such thickening of the walls as one frequently finds in the roots of Filicineae, nor any such specialized lacunar tissue as is typical of the stem and róots of most of the Lycopodiales, particularly of the Lepidodendraceae.

It will be seen from Fig. I and Fig. 3 that some of the inner layers of the cortex are slightly more elongated in the radial direction, while the outer layers appear in the transverse section somewhat flattened owing to the tangential extension of the cells. It will be convenient, therefore, to use the terms exo- and medio-cortex for these two portions of the cortex in the same sense in which they have been used by Groom ('95) in his descriptions of the roots of monocotyledonous saprophytes where they show a similar differentiation. The difference between these two layers of the cortex can most readily be seen in the longitudinal section (Fig. 3) in which it will be further seen that the innermost row of cortical cells (endo-cortex, possibly endodermis) is drawn out longitudinally, while the tangentially and radially elongated cells of the exo-and medio-cortex are short, more particularly the latter. The radially elongated cells, as can be seen both in the transverse and in the longitudinal sections (Figs. I and 3), are also characterized by their very dark contents. These will be described in detail later on, but it may be mentioned at present that they show indications of fungal hyphae and closely resemble in their appearance and in their position in the cortex the curious contracted masses (clumps) described by various authors in the aerial roots of Orchids and in the absorptive organs (roots or rhizomes) of saprophytic Monocotyledons and of Psilotum. The exo-cortex, though also containing hyphae, possesses none of these 'clumps,' and consequently looks at first sight devoid of the Fungus. This specialization of the hyphae in two different regions of the cortex is a very common phenomenon in mycorhizae and is constantly met with in the plants mentioned above. Fungal hyphae are very rarely met with in the endo-cortex. Only in one transverse section were a few hyphae discovered in this layer. This, again, is in conformity with the behaviour of the fungal mycelium in the mycorhizae of living plants, and supports the conclusion I have arrived at, that the Fungus is not of a destructive nature; or it would probably have penetrated into all the living tissues of the plant.

The cells of the epidermis are smaller in size than the cortical cells as can be seen in Plate XVIII, Figs. I and 3, and are often drawn out into long absorptive hairs (Plate XIX, Fig. 2). This piliferous layer may possibly be regarded as evidence of the root-nature of the organ, but it 
must be remembered the rhizome of Psilotum and Tmesipteris, as well as some of the modified absorbing rhizomes of saprophytes, bear such hairs. It is indeed difficult, as Groom ('95, II) has shown, to distinguish between roots and rhizomes in these plants, as they may be very considerably altered both externally and internally. Not only may the leaves be considerably atrophied but, as Groom points out, 'the structure of the stele in absorbing rhizome-axes of hemi- and holo-saprophytes is frequently remarkably like that of a root (Corysanthes, Burmannia, Corallorhiza), so the root-like structure of the stele of the absorbing organ is no proof of its root-nature.' It would seem, therefore, best to suspend our judgement with regard to the nature of the organ in question, and similarly we shall have to remain in doubt as to the systematic position of the plant until other portions of it have been discovered.

\section{The Fungus.}

The general distribution of the mycelial threads within the host-plant has been mentioned above as well as the different appearance of the Fungus in the exo-cortex and medio-cortex respectively. In the epidermis too hyphae may be noticed, but their occurrence in a cell does not necessarily mean that this has been a centre of infection. Sometimes, as in the cell bearing a root-hair in Plate XIX, Fig. 2, hyphae may be running longitudinally through the cell. Sometimes, however, numerous hyphae are seen running radially across the epidermal cells ( $h$ in Fig. 2 ); but in no case have I been able to trace them beyond the outer wall. Even in such cases, however, we have no proof that it was through these cells that the Fungus had gained admission, as it is known that hyphae may grow out from the mycorhiza into the surrounding medium. Thus Groom ('95, II), in his description of Thismia, mentions (p. 354) that it is possible to observe 'that frequently free hyphae are deserting, not entering, the host-plant.' Whether the particular hyphae shown in Fig. 2 are entering or leaving the tissues must of course remain an open question in the case of a fossil plant.

In the outer cortical layers the course of the Fungus is somewhat irregular, both horizontally and vertically running hyphae being met with. On the whole, however, the mycelium seems to grow along the mycorhiza just as Janse ('97) observed in many of the roots which he investigated. Plate XIX, Fig. I, which is a portion of the transverse section represented on Plate XVIII, shows the majority of the hyphae cut more or less transversely, and also exhibits them running, as they seem generally to do, close along the inner face of the cell-walls. This is often found to be the case in the living mycorhizae, where, however, the Fungus often forms more or less definite coils on the inside of the cell-walls. From these thicker coiled hyphae very thin haustorial filaments are sent into the 
cell-contents in Neottia, Psilotum and other plants according to Werner Magnus ('00) and Shibata ('02). But as these are very delicate, and soon disappear, we should not expect to find them in the exo-cortex of the fossil plant. Otherwise the latter presents very much the same appearance as it does in recent plants. In one or two cases the numerous hyphae attached to the inner walls of these cortical cells remind one of the mycelial pegs described by Groom ('95) in the roots of Galeola.

For the most part the hyphae seem to be intra-cellular, but there are indications that a few of them run between the cells. In no case, however, is there any sign that the Fungus was in any way destroying the tissues of the host-plant. In some of the cells of the exo-cortex curious pear-shaped bodies are found at the ends, or apparently at the ends, of certain hyphae. These may be fairly numerous, as in Plate XIX, Fig. 3, or there may be only two or three in a cell. They are generally most numerous in the sub-epidermal cells, while in the deeper layers of the exo-cortex they are fewer in number, larger in size, and more rounded. They resemble somewhat the pear-shaped swellings described and figured by Williamson ('81) on the hyphae of Peronosporites antiquarius, a Fungus found in the bark of Lepidodendron. Such pear-shaped bodies are, however, of very common occurrence in the outer cortical layers of recent mycorhizae. Thus in Psilotum, Janse ('97) figures a dozen of them in a subepidermal cell, just as they occur in the fossil mycorhiza. The nature of these vesicles, formed by endophytic Fungi, is a much-disputed point. Some authors look upon them as possibly of the nature of reproductive organs. Thus Bruchmann ('85) considered that they might possibly be oosporangia, while Goebel ('87) thought they might be gonidia (Dauergonidien) in the case of the Fungus inhabiting Lycopodium, which they supposed to be related to Pythium. Groom ('95), on the other hand, who made a very careful examination of these bladders and their mode of formation in the mycorhiza of Thismia, found that they were not terminal but intercalary dilatations, though appearing terminal by hypertrophy. $\mathrm{He}$ is consequently inclined to attribute a nutritive function to them, and regards them as of importance in increasing the absorptive area of the Fungus which is supposed to feed upon the host-plant in the outer cortical layers. This view of the purely vegetative character of the vesicles had also been entertained by Mollberg, who was apparently the first observer of these intercalary hypertrophies of the Fungus (in Platanthera and Epipactis). Groom found that the vesicles accumulated a large amount of denselystaining cytoplasm, which afterwards became vacuolated and diminished in amount, ultimately degenerating and depositing ' a homogeneous yellow substance in which are rod-like bodies which remind one of the regular rod-like bacteroids in leguminous tubercles.'

In the fossil plant the vesicles, whether large or small, are generally 
devoid of contents, but a few of the larger more rounded ones show homogeneous contents. In one or two instances vesicles were found among the cells containing the dark clumps and these contained what appear to be spores (Plate XIX, Fig. 6), but as they are really in the medio-cortex it is possible that they were formed in a different manner from the vesicles described above. In some cells lying near those with large vesicles (see Plate XIX, Fig. 5) there are found curious granules distributed very evenly through the cell and apparently attached to the cell-wall. The nature and formation of these I was not able to elucidate from the specimens at my disposal.

In the medio-cortex, as described above, we find the characteristic clump formation (see Plate XVIII, Figs. I, 3, and Plate XIX, Fig. 4)the clumps consisting no doubt partly of the cell-contents, partly of fungal filaments; but they are as a rule so dark in colour that no details of their structure can be made out. They are connected to the cell-walls by threads, which are sometimes very delicate and appear as if they were protoplasmic filaments, though they are probably contracted hyphae, as these can in some cases be seen very clearly as shown in Plate XIX, Fig. 4. These hyphae are, however, usually thinner and more delicate than those in the outer layers of the cortex. In this particular the fossil mycorhiza agrees with recent ones in which various observers have noted this difference. The fossil mycorhiza can of course give us no clue as to the formation and significance of these clumps, but their excellent preservation in a fossil condition may be considered to support the view of Werner Magnus ('00), that they consist of the non-digestible and unalterable remains of the Fungus after the host-plant has derived from it all possible nutriment. For the fact that these clumps are so well preserved would indicate that the Fungus had passed into an unalterable condition before fossilization.

Should the same degenerative changes have taken place in the mediocortex of the fossil plant as take place in recent mycorhizae these would readily explain such appearances of degeneration as one meets with in some of the specimens. Thus in Fig. 8 will be seen curious vacuolated masses which, as indicated by the presence of delicate radiating filaments, are probably produced in a similar way to the mycelial clumps. They obviously correspond to the so-called 'traubenförmige Körper' described by Bernatzky ('99) in the rhizome of Psilotum. Ultimately they would seem to break up into separate particles not unlike bacteroids (Fig. 7), but which may also be compared to the curious 'Eiweisshyphen' described by Magnus ('00) in some of the cells of the medio-cortex (Verdauungszellen) in which the host-plant is digesting the Fungus.

The obvious resemblance between these clumps in the fossil plant and those of recent mycorhizae, together with the close agreement in the structure and behaviour of the Fungus in the outer layers of the cortex, 
with those of the Fungus in recent mycorhizae will, I think, be regarded as sufficient evidence for the conclusion that we are dealing in the case of this fossil plant with a mycorhiza or mycorhizome. The Fungus differs materially in its manifestations from other cases of endophytic Fungi so far observed in fossil plants, and in no way suggests that it was living either saprophytically or parasitically upon the host-plant. The excellent preservation of both the Fungus and the host-plant and the specialization of the cortex into two layers comparable with the 'Pilzwirthzellen' and 'Verdauungszellen' of recent mycorhizae, would suggest that, as in the case of the latter, the host-plant is deriving some benefit from the presence of the Fungus.

We cannot of course expect from the investigation of a fossil mycorhiza to elucidate the difficulties that surround the mycorhiza-question, but it is of no little interest to find that already at the Coal-Measure period Fungi and cormophytes exhibited a mutual adaptation of such complexity as that involved by the formation of a mycorhiza.

Of the systematic position it is difficult to say much on the slender evidence before us. I have not been able, in any of the longitudinal sections, in which one sees occasionally considerable lengths of the Fungus, to detect any transverse walls, and this would incline me to the belief that the Fungus belonged to the group of Phycomycetes. This view would be supported by the fact stated by Seward ('98), that the Phycomycetes certainly existed in Permo-Carboniferous times. Among recent endophytic Fungi showing symbiotic adaptation some apparently also belong to this group, according to Bruchmann ('85) and Goebel ('87).

The systematic position of the host-plant is almost as difficult to determine as that of the Fungus. Leaving out of consideration the Gymnosperms and Cycadofilices with which it shows no affinities, we may confine ourselves to the consideration of the Vascular Cryptogams. Of the four divisions of these it seems, as mentioned above, to have most affinity to the Lycopodiales, though it differs considerably from most of these. It has not the specialization of the cortical tissues characteristic of the Lepidodendraceae and, if it is a root, does not possess the usual monarch arrangement found in that group. The absence of large intercellular passages such as are found in the roots of Lepidodendraceae and Calamarieae would lead us to infer that it was not rooted in marshy ground as were probably these larger fossils, and its association with a Fungus would rather point to a saprophytic existence in rich leafmould or to an epiphytic existence like that of Tmesipteris on the stems of Tree-ferns. In either case it would be likely to become infected with fungal hyphae, and might develop the special adaptation which its mycorhiza exhibits. That a mycorhiza has not been found in other Coal-Measure plants should not astonish us when we remember that 
the greater number of Lycopodiales and Equisetales were probably rooted in marshy places in which the conditions would not be very favourable to the formation of mycorhizae. In our present state of uncertainty as to the nature of the host-plant, of which the root or rhizome only is known, it would not be advisable to give it more than a provisional name, merely to facilitate reference to the specimen. For such use it would be best to employ a non-committal designation, like that of Rhizoniumwhich was invented by Corda ('45) to describe certain roots which he took to be those of an Orchidaceous type, and which was afterwards used by Williamson ('89) for the roots of an unknown plant. In consideration of the peculiar character of the fossil described above, I would suggest that, until we know more about the plant to which it belonged, it should be referred to as Mycorhizonium.

\section{LIST OF WORKS REFERRED TO.}

Bernatzky, '99: Beiträge zur Kenntniss der endotropen Mycorhizen. Természetrajzi Füzetek, I 899. Bertrand, C. E., '82: Recherches sur les Tmésipteridées. Archives botaniques du Nord de la France, I882.

'85: See Rénault and Bertrand.

Binney, E. W., '62: Trans. of the Manchester Geol. Soc. I862, vol. vi.

Bruchmann, H., '85 : Das Prothallium von Lycopodium. Bot. Centralblatt, Bd. xxi, I885.

CORDA, A. J., '45 : Beiträge zur Flora der Vorwelt,' 1845 .

Goeber, K.,'87 : Ueber Prothallien und Keimpflanzen von Lycopodium inundatum. Bot. Zeit., I887.

Groom, P., '95, I: Contributions to the knowledge of Monocotyledonous Saprophytes. Journal of the Linn. Soc., I895.

'95, II : On Thismia Aseroe and its Mycorhiza. Annals of Bot., ix, 1895 .

JANse, J. M., '97: Les endophytes radicaux de quelques plantes javanaises. Ann. du Jard. de Buit. xiv, 1897 .

Lomax, J., '02: On the occurrence of nodular concretions (Coal Balls) in the Lower Coal Measures. Ann. of Bot., xvi, I902.

Magnus, P., '03: Ein von F. W. Oliver nachgewiesener fossiler parasitischer Pilz. Ber. d. deutsch. Bot. Ges., xxi, r9o3.

MAgnus Werner, '00: Studien an der endotropen Mycorhiza von Neottia Nidus avis. Jahrb. f. wiss. Bot., I900.

Oliver, F. W., '03: Notes on fossil Fungi. New Phytologist, vol. ii, I903.

Renault, B., '83 : Cours de Bot. Fossile, vol. iii, I883.

Renault, B. and Bertrand, C. E., '85: Grilletia sphaerospermi, Chytridiacée fossile du terrain houiller supérieur. Comptes rendus, tome c, $188_{5}$.

Schimper, W. P., and Schenk, A., '90 : Palaeophytologie. In Zittel's Handbuch der Palaeontologie, I 890.

Seward, A. C., '98: Fossil Plants I, I898: Cambridge Nat. Science Manuals.

Shibata, K., '02: Cytologische Studien über endotrophe Mycorhizen. Jahrb. f. wiss. Bot., I902.

Williamson, W. C., '81 : Organization of the Fossil Plants of the Coal Measures, Part XI, I88I. 


\title{
Weiss.-A Mycorhiza from the Lower Coal-Measures. 265
}

\section{EXPLANATION OF PLATES XVIII AND XIX.}

\author{
Illustrating Professor Weiss's paper on a Mycorhiza from the Coal-Measures.
}

(Photographs by Mr. Abraham Flatters, Manchester.)

\section{PLATE XVIII.}

Fig. I. Transverse section of a mycorhiza from the Cash Collection in the Manchester Museum (Q. 827), about I mm. diameter. Above the section are seen some dark oval masses, probably the excrements of a wood-eating animal. In the exo-cortex $(e x)$ traces of the fungal hyphae can be seen projecting from the cell-walls into the cell-spaces. In the medio-cortex $(m c)$ are seen dark masses (clumps) consisting largely of fungal remains.

Fig. 2. Vascular cylinder of another mycorhiza $2 \mathrm{~mm}$. diameter from the same slide as Fig. I (Q. 827), showing a well-marked endo-cortex (en). Between the two groups of wood-elements are a few parenchymatous cells containing numerous granules. $p s=$ phloem-sheath.

Fig. 3. Longitudinal section of a mycorhiza from Dr. Scott's preparation (No. I 527), showing the vascular cylinder, the endo-cortex (en), the radially-elongated medio-cortex (m.c) with dark mycelial clumps, the exo-cortex $(e x)$ with scattered hyphae.

Fig. 4. Portion of the medio-cortex from a tangential longitudinal section on Dr. Scott's slide (No. I $^{27}$ ), showing the dark mycelial clumps $(c l)$. An enlarged drawing of a portion of this photograph is shown in Fig. 4, Plate II.

\section{PLATE XIX.}

Fig. I. A portion of the external tissues of the root figured in Plate I (Cash Collection, No. 527), showing the fungal hyphae $(h)$ in the exo-cortex and one of the cells of the medio-cortex with clump formation (c).

Fig. 2. A portion of the epidermis from a transverse section of another root, from the same slide as Fig. $\mathrm{I}$, showing the radial course of the fungal hyphae $(h)$ in an epidermal cell. $\quad r . h=$ root-hair.

Fig. 3. Formation of vesicles by the fungal hyphae in the sub-epidermal layer. Portion of the longitudinal section from Dr. Scott's collection shown in Plate XVIII, Fig. 3.

Fig. 4. Enlarged view of a portion of medio-cortex shown in photograph 4 on Plate XVIII, to show the hyphae connecting the mycelial clumps with the cell-walls.

Fig. 5. Portion of the cortex of transverse section on Slide No. I527 (Dr. Scott's Collection), showing one of the large vesicles found near the medio-cortex, and also a cell containing curious granulations (see p. 262).

Fig. 6. Portion of the tangential section on Dr. Scott's preparation (No. I527), showing sporangia (?) $(s p)$ and spores (?) in a cell of the medio-cortex. The other cells contain mycelial clumps $(c l)$.

Fig. 7. A cortical cell from a transverse section on Slide 529 of the Cash Collection, in which the cell-contents seem to have undergone degeneration.

Fig. 8. Two cortical cells from the same section as Fig. 7 , showing earlier stages of degeneration of cell-contents with indication of previous formation of mycelial clumps. 

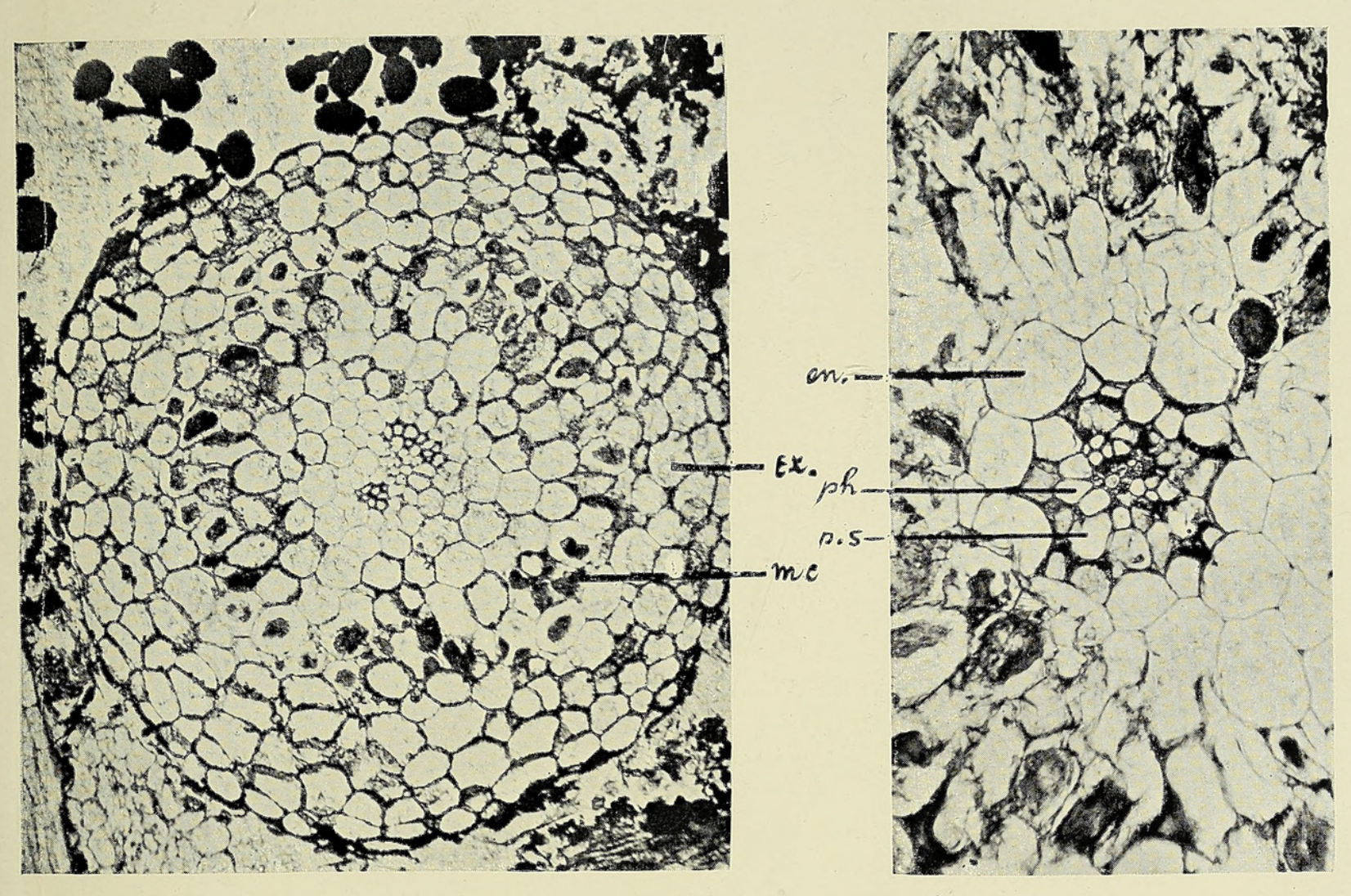

3.
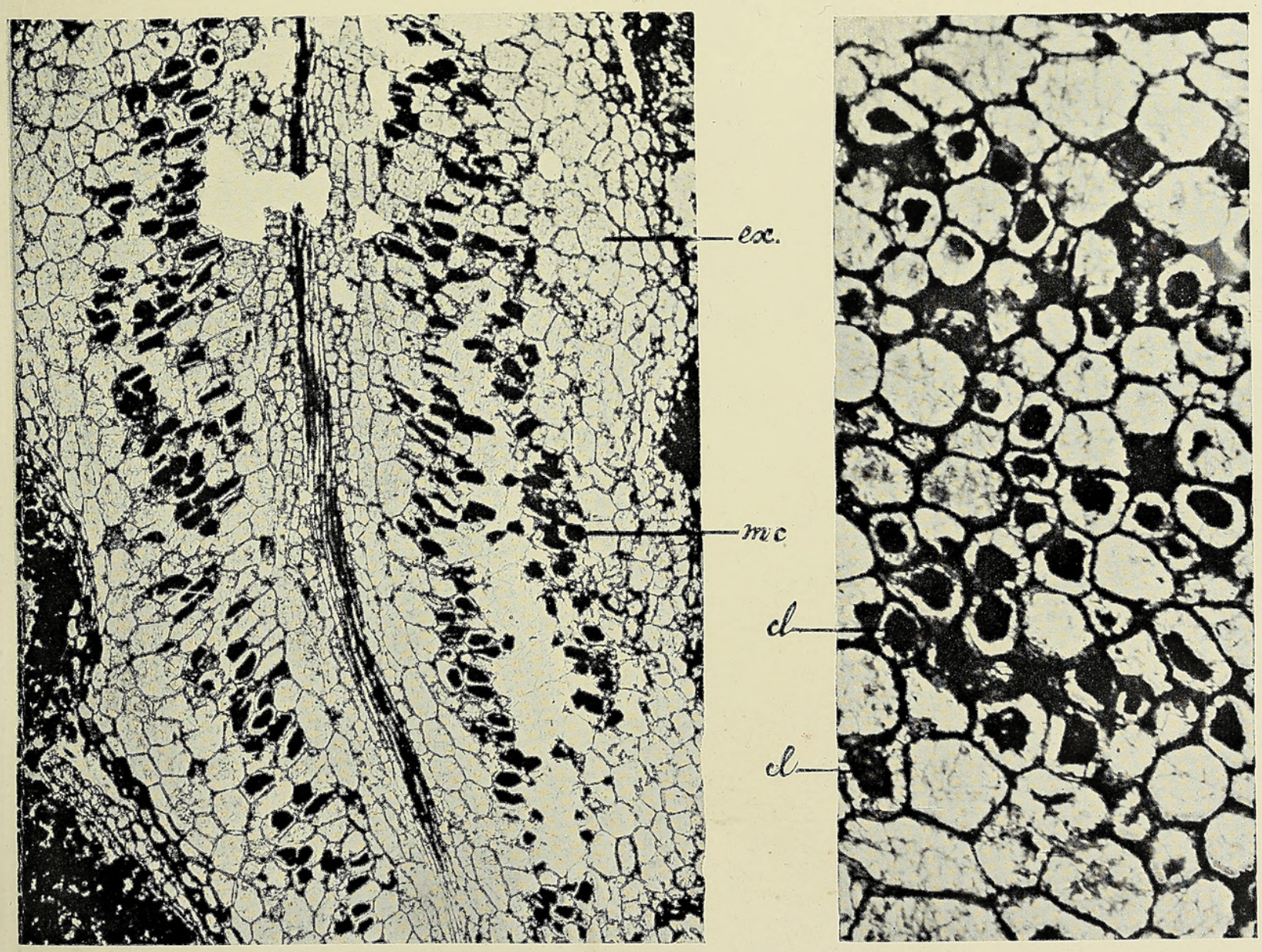
Aruals of Botany.
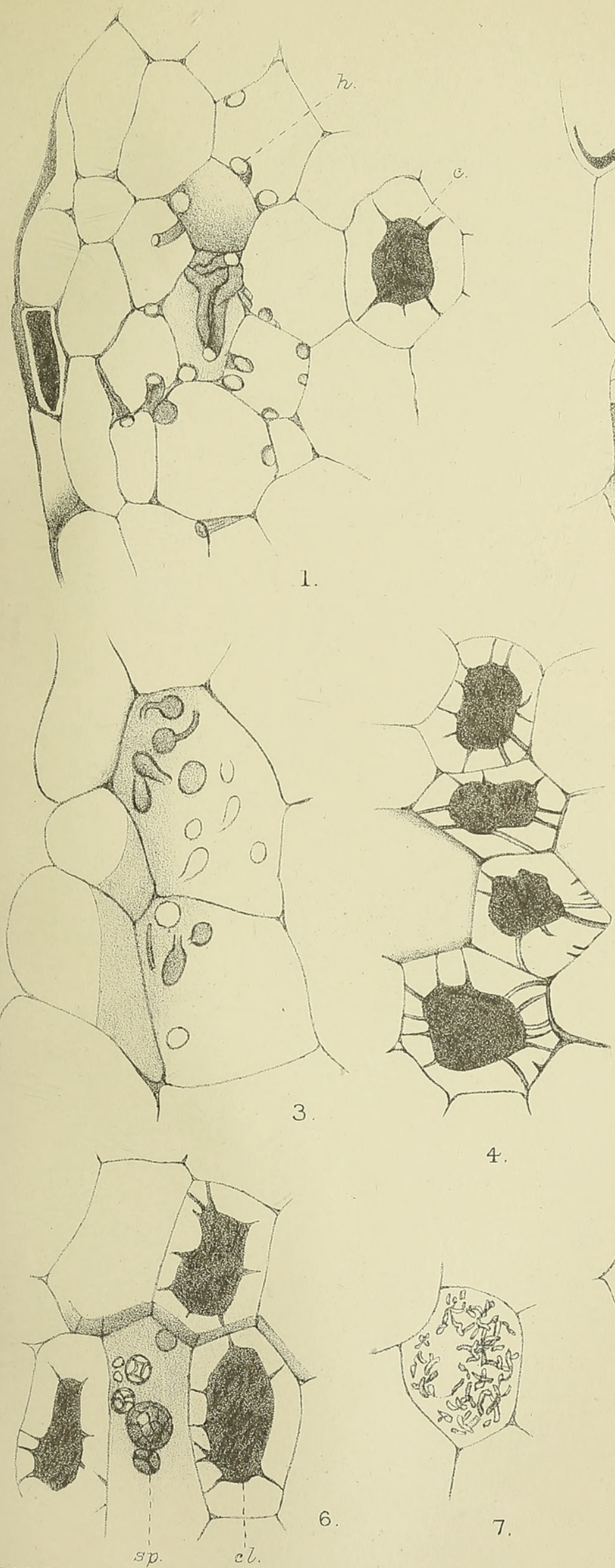

4.

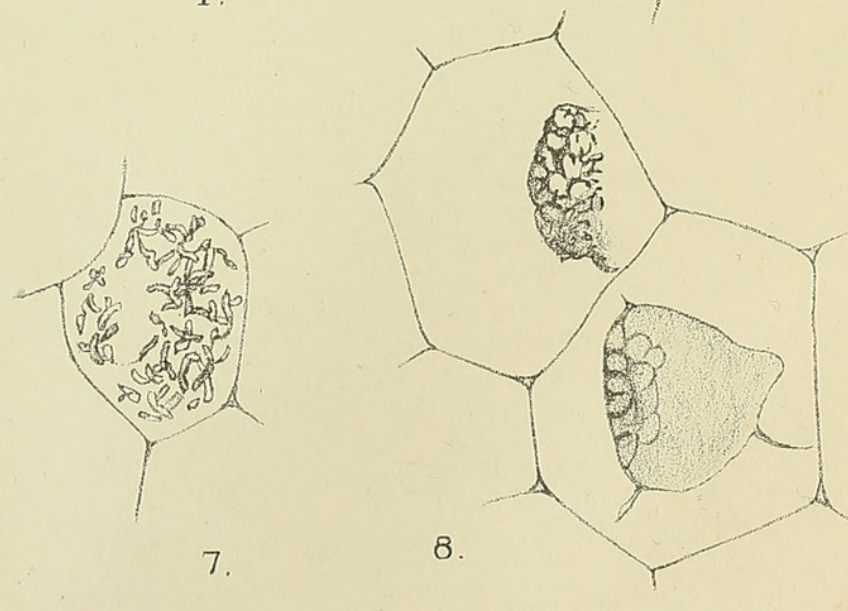

Univer sity $\operatorname{Press}, 0 x$ ford

F.E.W. del.
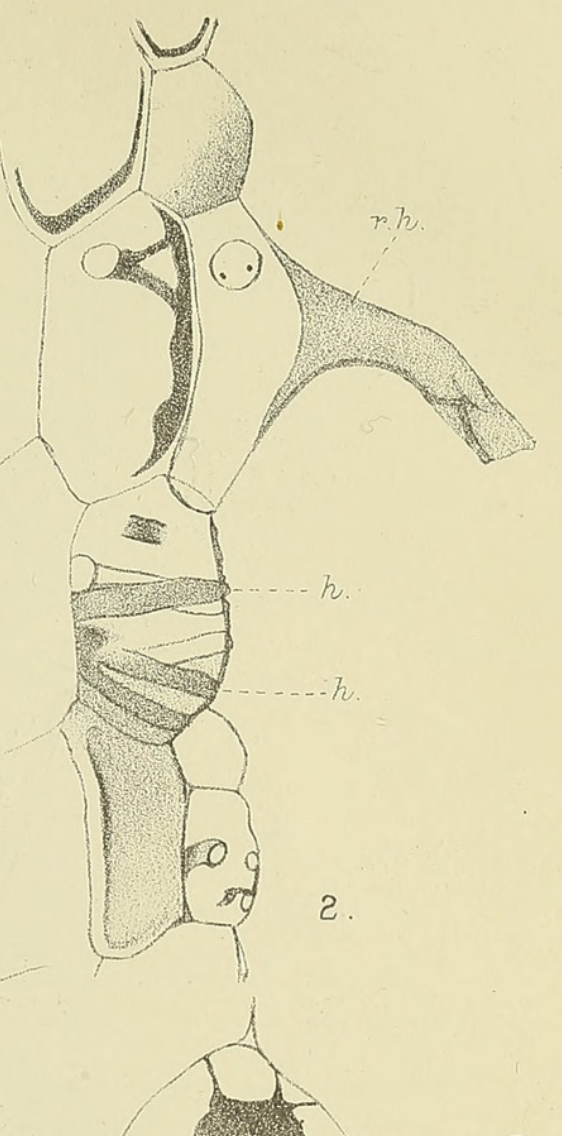


\section{$2 \mathrm{BHL}$ Biodiversity Heritage Library}

Weiss, F. E. 1904. "A mycorhiza from the lower coal-measures." Annals of botany 18, 255-265. https://doi.org/10.1093/oxfordjournals.aob.a088961.

View This Item Online: https://www.biodiversitylibrary.org/item/234469

DOI: https://doi.org/10.1093/oxfordjournals.aob.a088961

Permalink: https://www.biodiversitylibrary.org/partpdf/318759

\section{Holding Institution}

Smithsonian Libraries

\section{Sponsored by}

Biodiversity Heritage Library

\section{Copyright \& Reuse}

Copyright Status: Not in copyright. The BHL knows of no copyright restrictions on this item.

This document was created from content at the Biodiversity Heritage Library, the world's largest open access digital library for biodiversity literature and archives. Visit BHL at https://www.biodiversitylibrary.org. 